\title{
PUBLIC HEALTH RESEARCH PRIORITIES IN EUROPE SEEN BY NON-GOVERNMENTAL ORGANIZATIONS
}

\author{
Gabriel Gulis ${ }^{1}$, Lara Garrido-Herrero², Zuzana Katreniakova ${ }^{3}$, Gabrielle Harvey ${ }^{4}$, Mark McCarthy ${ }^{4}$ \\ ${ }^{1}$ University of Southern Denmark, Niels Bohrsvej, Esbjerg, Denmark (in project on behalf of the Slovak Public Health Association - SAVEZ) \\ European Public Health Alliance, Brussels, Belgium \\ ${ }^{3}$ Department of Social Medicine, Medical Faculty, University of PJ Safarik, Kosice, Slovakia (in project on behalf of the Slovak Public Health \\ Association - SAVEZ) \\ ${ }^{4}$ Department of Epidemiology and Public Health, University College London, London, UK
}

\begin{abstract}
SUMMARY
Background. Public health research is concerned with population health, determinants of health, health systems research, health promotion, environmental health, health protection, disease prevention and research in other fields of public health. During the last decades, non-governmental organisations (NGOs) are more often entering the field of public health research. This paper presents results of work within SPHERE (Strengthening Public Health Research in Europe), a European Commission funded study aimed to gather information and produce knowledge on the state of public health research in Europe.

Methods. A questionnaire survey was developed and conducted among NGOs enrolled in a database held by the European Public Health Alliance (EPHA). There were 80 replies, and the response rate for NGOs that were members of EPHA was 53\%.

Results. There were no significant statistical differences in the responses when analysed for three European groups ['old' member states (EU 15), accession members states in 2004 (EU 10) and EU-associated countries]. The NGOs reported a relatively large international experience, expressed by participation in international public health research, and more often practice work. The main research priorities reported were general public health, environmental health, ADHD, obesity, nutrition, tobacco control. NGOs showed low correlation between their work field and their proposed public health research priorities.

Conclusion. There are growing numbers of NGOs in Europe concerned with public health. This survey indicates their interest also in public health research priorities.
\end{abstract}

Key words: varicella zoster virus, seroepidemiologic studies, immunity, vaccination, public health policies

Address for correspondence: G. Gulis, University of Southern Denmark, Niels Bohrsvej 9-10, 6700 Esbjerg, Denmark.

E-mail: ggulis@health.sdu.dk

\section{INTRODUCTION}

Public health research is concerned with population health, determinants of health, health care systems, environmental health, health promotion, health protection and disease prevention. It complements biomedical research, which is concerned with biomedical mechanisms of disease and medical treatments. In contrast to the laboratory or clinical level of biomedical research, public health research is undertaken at population level. The Global Forum for Health Research defines three main categories of health research - strategic research, biomedical research and behavioral research (1). Public health research, in the meaning of this paper comprises strategic and behavioral research. Public health research, as public health practice, aims to be intersectoral. A contemporary challenge for public health research is to integrate the capabilities of different academic disciplines to address policies for health on one side, and to improve implementation of research results on the other side. As well as standard public health research institutions, such as national public health research institutes, universities, public and private sectoral research insti- tutes, non-governmental organizations have entered the public health research field during the last decades.

The term non-governmental organization (NGO) is used in a variety of ways all over the world and, depending on the context in which it is used, can refer to many different types of organizations. In its broadest sense, a non-governmental organization is one that is not directly part of the structure of government (2). Often, NGOs bring together people with different expertise but a shared interest to act on a common good. Public health area is not an exception. However, most of public health related NGOs focus on public health field-work, practice, advocacy, and at some extent policy development.

SPHERE (Strengthening Public Health Research in Europe) is a collaborative study supported by the European Commission's Sixth Framework Research Programme (3) which aims to gather information and produce knowledge on the recent state of public health research in Europe. One work package in SPHERE focused on NGOs and their view of recent and future public health research priorities in Europe. This paper presents the results of this part of the study. 


\section{METHODS}

Collecting information on NGOs engagement in public health was carried out by:

- developing a questionnaire for data collection,

- identifying and contacting non-governmental organizations using the database of the European Public Health Alliance (EPHA), and a request to forward the questionnaire to other potentially interested NGOs.

The questionnaire was prepared and discussed by the two organizations involved in the project work package - the Slovak Public Health Association (SAVEZ) and EPHA. The questionnaire was sent out by email approximately to 1,500 contacts including the following: EPHA members (150 contacts), members of the European Health Policy Forum (47 contacts) and EPHA contacts in CEE countries (1,300 contacts).

A few months later, the questionnaire was re-sent to the same database contacts, which had been increased in size during those months due to new additions from Romanian NGOs and new EPHA members. The total recipients including the second wave were around 1,600 contacts.

It is very hard to express a response rate due to different sources of contacted NGOs. Taking in account only NGOs in EPHA database (150) the response rate is quite high, about $53 \%$. On other side, considering the whole number of about 1,600 contacted NGOs the response rate is low. The truth might be closer to the first calculation; the EPHA database likely contains NGOs who are really active in the field of public health.

Statistical analysis was focused on country groups comparisons - the EU15 (EU countries before May 1st 2004), EU10 (those countries who joined EU at May 1st 2004) and non-EU countries. Simple descriptive statistics were used to describe differences between country groups (mean values, P-values). To assess correlation between working area of an NGO and proposed priorities, Pearson's correlation coefficients calculation was used.

\section{RESULTS AND DISCUSSION}

Filled questionnaires were received from 80 different organizations in 28 European countries, 71 of them were NGOs. The remaining 9 responses came from organizations who changed their status to other entity as NGO over time. Respondents came from all around Europe. The following shows the geographic distribution of received responses by countries:

- EU27 (15+10+2):

- UK 5, Belgium 5, Germany 3, the Netherlands 3, Greece 3, Austria 3, Ireland 3, Italy 2, Sweden 2, Luxembourg 1 , Spain 1 - total 31

- Cyprus 6, Slovenia 4, Czech Republic 3, Hungary 3, Poland 3, Slovakia 3, Estonia 2, Latvia 1, Lithuania 1, Malta 1 - total 27 - Non EU:

- Macedonia 5, Armenia 2, Turkey 2, Switzerland 1, Croatia 1 , Norway 1 , Serbia and Montenegro 1 - total 13

The mean duration of existence of NGOs that participated in the survey is 18.3 years (standard deviation 23.3 years). The median of 14 years reflects that the mean is slightly shifted toward higher values by couple of older, long time existed NGOs. Table 1 presents the duration of existence by year groups.
Table 1. NGOs' duration of existence and numbers of NGOs

\begin{tabular}{|c|c|}
\hline $\begin{array}{c}\text { Years of establishment of NGOs } \\
\text { (up to 2005) }\end{array}$ & Number (\%) of respondents \\
\hline $0-5$ & $17(24.7)$ \\
\hline $6-10$ & $13(18.8)$ \\
\hline $11-15$ & $15(21.7)$ \\
\hline $16-20$ & $10(14.5)$ \\
\hline$>=21$ & $14(20.3)$ \\
\hline Total & $69(100)$ \\
\hline
\end{tabular}

Table 2 shows the number of respondents in different groups, depending on the work fields that the NGOs were concerned with. Only those respondents that answered this question are included. It is of note that only four of the respondents listed research as one of their main fields of work.

Looking at work fields by membership in EU country groups (EU15, EU10 and non-EU) no statistically significant difference was found $(\mathrm{P}=0.56)$.

Population health, environmental heath, attention deficit hyperactivity disorder, health and social care, mental health, cancer, and complementary and alternative medicine were the most frequent working areas reported by the NGOs. There is no significant difference in work fields between EU country groups (EU10, EU15, non-EU) ( $\mathrm{P}=0.76)$.

Considering the level on which NGOs activities are focused, $81 \%$ of responding NGOs work at national level, $14 \%$ at international, $3 \%$ at regional and only $2 \%$ at local level.

About $52.2 \%$ of responding NGOs $(n=37)$ claimed that they had experience working at international level, while $47.8 \%$ claimed no international experience $(n=34)$. Respondents reported having international experience on the following areas: consultancy services, collaborative projects, organizing and participating in international workshops, and attending meetings abroad.

NGOs presented a reasonable international experience in terms of membership in international networks of NGOs. Some of the respondents declared quite a higher number of developed partnerships, for example one NGO claimed membership in 10 international NGOs networks. In general, 51 NGOs reported membership in more than one international network or organiza-

Table 2. Workfields indicated by NGOs

\begin{tabular}{|l|c|}
\hline Work fields & $\begin{array}{c}\text { Number (\%) of } \\
\text { respondents }\end{array}$ \\
\hline Advocacy, networking, field work & $12(26.7)$ \\
\hline $\begin{array}{l}\text { Health promotion activities (health and human rights } \\
\text { protection) }\end{array}$ & $10(22.3)$ \\
\hline $\begin{array}{l}\text { Provision of services (care of people with disabilities, } \\
\text { chronic illness, etc) }\end{array}$ & $9(20)$ \\
\hline Training & $6(13.3)$ \\
\hline Research & $4(8.9)$ \\
\hline Awareness raising campaigns & $2(4.4)$ \\
\hline Financial support (donors, provision of grants) & $1(2.2)$ \\
\hline Standard setting & $1(2.2)$ \\
\hline Total & $45(100)$ \\
\hline
\end{tabular}


tion. This number is higher than the number of NGOs with international working experience because some NGOs are members of international networks but do not have yet significant international working experience. The mean number of memberships was 2.3 (standard deviation 2.4, median 2). There is no statistically significant difference in network memberships in country groups comparisons ( $\mathrm{P}=0.42)$. Most of the newest or less consolidated NGOs (specially in the new EU member states) are aware of the importance of international work and the importance of being a member of international networks in order to gain recognition at national level (recognition as reliable stakeholders by their government or Parliament, and increased attraction of independent funding).

Each of the NGOs which had experience working at international level reported its participation in at least one international project. Most of the NGOs are involved in one or two international projects, only one NGO claimed to be involved in 8 international projects and another one was involved in 9 projects. The nature of NGOs (normally small and poorly resourced) explains the tendency to be involved in one or two projects at the time.

Table 3. National and international level public health research priorities

\begin{tabular}{|l|c|c|}
\hline Public health research needs & National & $\begin{array}{c}\text { Interna- } \\
\text { tional }\end{array}$ \\
\hline Public health, population health & 11 & 9 \\
\hline Environment and health & 6 & 5 \\
\hline Attention deficit hyperactivity disorder & 5 & 2 \\
\hline Obesity, nutrition & 5 & 6 \\
\hline Tobacco & 4 & 5 \\
\hline Ageing & 4 & 4 \\
\hline Cancer & 4 & 2 \\
\hline Awareness research & 4 & 4 \\
\hline Economic, social determinants of health & 4 & 2 \\
\hline Mental health & 3 & 5 \\
\hline Injury prevention & 3 & 2 \\
\hline Smaller size research & 3 & 4 \\
\hline Sexual and reproductive health & 2 & 3 \\
\hline Hospital care, palliative care, post-hospital \\
and home care & 2 & 0 \\
\hline Pharmaceutical products & & \\
\hline Behavioral health & 2 & 1 \\
\hline $\begin{array}{l}\text { Health care systems, reforms, finances, } \\
\text { access }\end{array}$ & 2 & 0 \\
\hline Private sector collaboration & 2 & 6 \\
\hline Child safety, violence & 2 & 0 \\
\hline DALY, burden of disease & 1 & 0 \\
\hline Health education, promotion & 1 & 1 \\
\hline Drug use, injecting drug use & 1 & 0 \\
\hline Diabetes & 2 & 2 \\
\hline Medical education & 1 & 1 \\
\hline Cardiovascular disease & 2 & \\
\hline Meningitis & 2 & 1 \\
\hline
\end{tabular}

Table 3. (continues)

\begin{tabular}{|l|c|c|}
\hline Public health research needs & National & $\begin{array}{c}\text { Interna- } \\
\text { tional }\end{array}$ \\
\hline Human rights & 1 & 1 \\
\hline Rheumatism & 1 & 1 \\
\hline Allergies & 1 & 1 \\
\hline Rare diseases & 1 & 0 \\
\hline HIVIAIDS & 1 & 0 \\
\hline Rural health & 1 & 1 \\
\hline Anemia & 1 & 0 \\
\hline National health surveys & 1 & 0 \\
\hline Health inequalities & 1 & 0 \\
\hline Scientific writing & 1 & 2 \\
\hline Efficiency of Chinese medicine & 1 & 1 \\
\hline Asthma & 1 & 1 \\
\hline Physical activity & 1 & 0 \\
\hline Cost effectiveness of prevention, treatment & 1 & 4 \\
\hline Community resilience & 1 & 0 \\
\hline Patient registry & 1 & 0 \\
\hline Quality improvement & 1 & 0 \\
\hline Health and social care & 1 & 0 \\
\hline Nursing, midwifery & 1 & 1 \\
\hline Lifestyle & 0 & 4 \\
\hline Implementation research & 0 & 3 \\
\hline Health and social care & 0 & 3 \\
\hline Based on WHO recommendations & 0 & 1 \\
\hline Data collection systems & 0 & 1 \\
\hline Support to South East Europe & & 1 \\
\hline
\end{tabular}

The main objective of this research was to find out about the opinions of NGOs regarding the priorities for public health research. In most cases, the respondents listed more than one priority. Table 3 shows the priorities.

There is a high level of comparability in national (regional) and international public health research priorities as seen by NGOs.

There were no statistically significant country groups differences for both, national and international public health research priorities (P-values were 0.28 and 0.36 , respectively).

A correlation was also investigated between the work field of a NGO and its stated research priorities. The purpose of correlation calculation of two relatively independent variables was to check whether they are indeed independent; to check whether NGOs see their on work area as a main research priority or they look rather broader to national and international public health research needs. Pearson's correlation coefficients were 0.21 and 0.26 comparing national and international research priorities and work area of NGO. This suggests that NGOs do not focus on their own field only; they seem to be rather objective and independent.

Table 4 presents international public health research priorities of NGOs by country of origin. 
Table 4. International research priorities by country of origin

\begin{tabular}{|c|c|}
\hline Country & International public health research needs \\
\hline Armenia & $\begin{array}{l}\text { public health system research, enforcement, environmental } \\
\text { health, biomonitoring }\end{array}$ \\
\hline Austria & $\begin{array}{l}\text { smaller size research, mental health, efficiency, implemen- } \\
\text { tation research }\end{array}$ \\
\hline Belgium & $\begin{array}{l}\text { mental health, tobacco control, abuse prevention, patient } \\
\text { safety, obesity, nutrition, aging, medical education, harmoni- } \\
\text { zation of European health care system, intersectorality }\end{array}$ \\
\hline Croatia & implementation research \\
\hline Cyprus & $\begin{array}{l}\text { epidemiological research to cover areas not yet studied, } \\
\text { rheumatism, general public health, determinants of health, } \\
\text { awareness campaign }\end{array}$ \\
\hline $\begin{array}{l}\text { Czech } \\
\text { Republic }\end{array}$ & $\begin{array}{l}\text { efficiency of tobacco control measures, smoke free life, } \\
\text { evaluation research, health care provision across EU, } \\
\text { efficiency of Chinese therapy, allergic asthma, dysmenor- } \\
\text { rhoea, sterility problems }\end{array}$ \\
\hline Estonia & knowledge management, knowledge sharing \\
\hline Germany & $\begin{array}{l}\text { pharmaceutical research, access to medicines, public private } \\
\text { partnership, financing, ADHD (Attention Deficit Hyperactivity } \\
\text { Disorder) }\end{array}$ \\
\hline Greece & mental health, aging, best in public health \\
\hline Hungary & $\begin{array}{l}\text { global data collection, organization, publicity, distribution, } \\
\text { financial support, environmental health }\end{array}$ \\
\hline Ireland & $\begin{array}{l}\text { ADHD in international research, data collection, genetic, } \\
\text { epidemiological situation in all countries, environmental } \\
\text { health, health impacts of genetically engineered food }\end{array}$ \\
\hline Italy & $\begin{array}{l}\text { ADHD in international research, data collection, genetic, } \\
\text { epidemiological situation in all countries, health care provi- } \\
\text { sion across EU, tobacco, alcohol, mental health, technol- } \\
\text { ogy, violence }\end{array}$ \\
\hline Latvia & possibilities for smaller societies to take part of programs \\
\hline Lithuania & allergies \\
\hline Luxembourg & pregnancy, birth conditions, infant nutrition \\
\hline Macedonia & health education, patient rights, \\
\hline Norway & $\begin{array}{l}\text { lifestyle related studies, addiction and sources of addiction, } \\
\text { differences in Europe }\end{array}$ \\
\hline Poland & $\begin{array}{l}\text { health care provision across EU, tobacco control, health } \\
\text { determinants, lifestyle and health, health impacts of multiple } \\
\text { exposures, allergies, genetic polymorphism and diseases }\end{array}$ \\
\hline $\begin{array}{l}\text { Serbia and } \\
\text { Montenegro } \\
\end{array}$ & aging, rural health, women \\
\hline Slovakia & $\begin{array}{l}\text { healthy lifestyle, cancer prevention, health care provision } \\
\text { across EU, scientific publication quality improvement network }\end{array}$ \\
\hline Slovenia & aging \\
\hline Spain & sports, occupational health, schools, new health professionals \\
\hline Sweden & N.A. \\
\hline Switzerland & link of epidemiological research and health policy \\
\hline $\begin{array}{l}\text { the Nether- } \\
\text { lands }\end{array}$ & $\begin{array}{l}\text { obesity, physical activity, intersectorality, injury surveillance } \\
\text { and injury data exchange in Europe, good practices in } \\
\text { safety promotion }\end{array}$ \\
\hline Turkey & $\begin{array}{l}\text { reproductive health, gender discrimination, child abuse, } \\
\text { human trafficking, nutrition and obesity, elderly health }\end{array}$ \\
\hline UK & $\begin{array}{l}\text { public health benefits of drinking water, research into quality } \\
\text { and effectiveness of public information, healthcare profes- } \\
\text { sional education on rare diseases and client satisfaction }\end{array}$ \\
\hline
\end{tabular}

\section{CONCLUSIONS}

NGOs are organizations that are very vibrant, active and under constant change. In the present research, one of the hardest points is therefore to assess its representativeness. The usual measure of questionnaire surveys, response rate, is hard to apply because of the constant change. However, looking at geographic distribution, we gained wide coverage of countries, from Armenia to Ireland and from Cyprus to Norway. There were also no statistically significant differences among EU15, EU10 and non-EU countries. The responses showed significant international experience of the NGOs, including networking, collaborative project work and international consultancy. The work fields of NGOs seem to be often monothematic, focusing on a single public health issue. However, they identified a broad range of research priorities, both on national and international level. The low correlation between the NGOs' own work field and their stated research priorities indicates a broad perspective on public health: NGOs do not focus only on their own fields, but look into future and to needs of population.

Comparison of public health research priorities suggested by NGOs with the first call for public health research of European Commission's Seventh Framework Research Programme (4),and the Community Action Plan for Public Health of the Directorate for Health and Consumer Protection(5) indicates a relatively high level of agreement in themes.

\section{Acknowledgement}

SPHERE (Strengthening Public Health Research in Europe) was supported by the European Community Sixth Framework Programme 'Scientific Support to Policies'.

\section{REFERENCES}

1. Ghaffar A, de Francisco A, Matlin S, editors. The combined approach matrix: a priority setting tool for health research. Geneva: Global Forum for Health Research; 2004.

2. Wikipedia [homepage on the Internet]. Non-governmental organization [cited 2007 May 6]. Available from: http://en.wikipedia.org/wiki/Nongovernmental_organization.

3. UCL Department of Epidemiology and Public Health [homepage on the Internet]. SPHERE Strengthening Public Health Research in Europe [cited 2008 Jan 9]. Available from: http://www.ucl.ac.uk/public-health/ sphere/spherehome.htm.

4. Clarke A, McCarthy M, Alvarez-Dardet C, Sogoric S, Groenewegen P, Groot W, et al. New directions in European public health research: report of a workshop. J Epidemiol Community Health. 2007 Mar;61(3):194-7.

5. CORDIS: Community Research and Development Information Service [homepage on the Internet]. The Seventh Framework Programme (FP7) [cited 2007 May 6]. Available from: http://cordis.europa.eu/fp7/home_ en.html.

6. Public Health Executive Agency (PHEA) [homepage on the Internet]. Call for Proposals 2008 [cited 2007 May 6]. Available from: http://ec.europa. eu/phea/calls/call_for_proposals_en.html.

7. http://cordis.europa.eu/fp7/home_en.html, accessed May 6, 2007

8. http://ec.europa.eu/phea/calls/call_for_proposals_en.html, accessed May 6, 2007.

Received March 19, 2008 Accepted June, 2008 